\title{
Rancang Bangun Aplikasi Pemesanan Tiket Online Kapal Laut Berbasis Android
}

\author{
Deybi W. E. Sede, Alicia A. E. Sinsuw, Xaverius B. N. Najoan \\ Teknik Informatika Universitas Sam Ratulangi Manado, Indonesia. \\ deybi.khunnie@yahoo.co.id,, aliciasinsuw@gmail.com,xnajoan@unsrat.ac.id
}

\begin{abstract}
Abstrak - Sistem informasi Pemesanan Tiket merupakan sebuah data bentuk fisik yang diberikan oleh perusahaan kepada pelanggan untuk mendapatkan jasa dari perusahaan atau mendapatkan barang yang tertera di dalam nya. Tiket biasanya bebentuk kertas yang di dalamnya terdapat penjelasan tertentu yang menunjukan suatu nilai. Tujuan dari penelitian ini adalah untuk merancang aplikasi pemesanan tiket online kapal laut berbasis android dengan menggunakan metodologi DAD (Disciplined Agile Delivery) dan Memberikan informasi bagi masyarakat yang akan melakukan perjalanan menggunakan transportasi kapal laut, baik informasi mengenai kapal, jadwal pelayaran, pemesanan tiket ke masing-masing tujuan. Rancang bangun pemesanan tiket online kapal laut berbasis android telah berhasil di bangun dan di implementasikan dengan fitur aplikasi jadwal kapal, cek tiket, booking tiket dan mendaftar sebagai member.
\end{abstract}

Kata kunci — Android, D AD, Sistem Informasi Tiket

\section{PENDAHULUAN}

Perkembangan sistem informasi dalam kehidupan manusia seiring dengan peradaban manusia itu sendiri sampai akhirnya mengenal istilah Teknologi Informasi (IT/Information Technology). Mengikuti perkembangan teknologi yang diterapkan pada sarana transportasi sangat jarang ditemukan pada sarana transportasi laut yang bisa diakses melalui perangkat mobile, baik dari jadwal keberangkatan, informasi maupun untuk pemesanan tiket pada satu perusahaan. Maka dengan merancang sebuah aplikasi mobile berbasis android yang dapat menyelesaikan permasalahan tersebut. Aplikasi ini akan me manfaatkan akses cepat yang dimiliki oleh Android OS yang digunakan untuk melakukan pemesanan tiket kapal laut, mengetahui jadwal keberangkatan dari berbagai kapal yang akan berlayar di seputaran Nusa Utara (Tahuna-Talaud-Sitaro) sampai dengan pembayaran. Tujuan dari penelitian ini adalah untuk merancang aplikasi pemesanan tiket online kapal laut berbasis android dengan menggunakan metodologi DAD (Disciplined Agile Delivery) dan Memberikan informasi bagi masyarakat yang akan melakukan perjalanan menggunakan transportasi kapal laut, baik informasi mengenai kapal, jadwal pelayaran, pemesanan tiket ke masing-

\section{LANDASAN TEORI}

\section{A. Android}

Android (sistem operasi) - OS Android - Merupakan sebuah sistem operasi yang berbasis Linux untuk telepon seluler seperti telepon pintar dan komputer tablet. Android menyediakan platform terbuka bagi para pengembang untuk menciptakan aplikasi mereka sendiri untuk digunakan oleh bermacam peranti bergerak. Telepon seluler menggunakan berbagai macam sistem operasi seperti Symbian OS®, Microsoft's Windows Mobile $\AA$, Mobile Linux®, iPhone OS® (berdasarkan Mac OS X), Moblin ${ }^{\circledR}$ (dari Intel), dan berbagai macam sistem operasi lainnya.

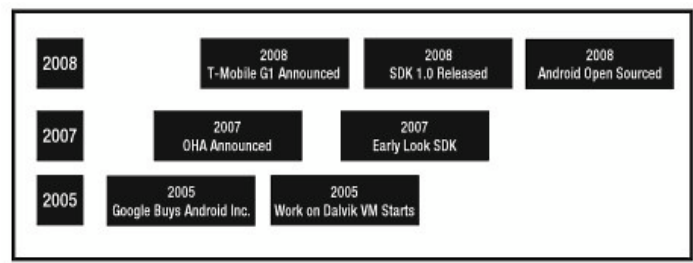

Gambar 1 Sejarah perke mbangan sistem opersi android

Android merupakan subset perangkat lunak untuk perangkat mobile yang meliputi sistem operasi, middleware dan aplikasi inti yang dirilis oleh Google. Sedangkan Android SDK (Software Development Kit) menyediakan tools dan API yang diperlukan untuk mengembangkan aplikasi pada platform android dengan menggunakan bahasa pemrograman java. Android disebut sebagai platform mobile pertama yang lengkap,terbuka, memecakan hambatan dan bebas. Penjelas annya sebagai berikut :

- Lengkap (complete platform) : android merupahkan sistem operasi yang aman dan banyak menyediakan tools dalam membangun software dan memungkinkan untuk pengegembangan aplikasi.

- Terbuka (Open Source Platform) : pengembang dapat dengan bebas untuk mengembangkan aplikasi

- Memecahkan hambatan pada aplikasi : Android memecah hambatan untuk membangun aplikasi yang baru dan inovatif. Misalnya, pengembang dapat menggabungkan informasi yang diperoleh dari web dengan data pada ponsel seseorang 
seperti kontak pengguna, kalender, atau lokasi geografis.

- Bebas (free Platform) : android adalah platform yang bebas untuk develop, tidak ada lesensi atau biaya royali untuk dikembangkan pada platform android.

\section{B. Eclipse}

Menurut Nasruddin Safaat h (Pemrograman aplikasi mobile smartphone dan tablet PC berbasis android 2012:16) Eclipse adalah sebuah IDE (Integrated Development Environment) untuk mengembangkan perangkat lunak dan dapat dijalankan di semua platform (platformindependent). Berikut ini adalah sifat dari Ec lipse:

a) Multi-p latform: Target sistem operasi Eclipse adalah Microsoft Windows, Linux, Solaris, AIX, HP-UX dan Mac OS X.

b) Multi-language: Eclipse dikembangkan dengan bahasa pemrograman Java, akan tetapi Eclipse mendukung pengembangan aplikasi berbasis bahasa pemrograman lainnya, seperti $\mathrm{C} / \mathrm{C}++$, Cobol, Python, Perl, PHP, dan lain sebagainya.

c) Multi-role: Selain sebagai IDE untuk pengembangan aplikasi, Eclipse pun bis a digunakan untuk aktivitas dalam siklus pengembangan perangkat lunak, seperti dokumentasi, test perangkat lunak, pengembangan web, dan lain sebagainya.

Eclipse pada saat ini merupakan salah satu IDE favorit dikarenakan gratis dan open source, yang berarti setiap orang boleh melihat kode pemrograman perangkat lunak ini. Selain itu, kelebihan dari Eclipse yang membuatnya popular adalah kemampuannya untuk dapat dikembangkan oleh pengguna dengan komponen yang dinamakan plug-in. Eclipse dibuat dari kerja sama antara perusahaan-perusahaan anggota 'Eclipse Foundation' (beserta individu-individum lain). Banyak nama besar yang ikut dalam 'Eclipse Foundation', termasuk IBM, BEA, Intel, Nokia, Borland. Eclipse bersaing langsung dengan Netbeans IDE. Plugin tambahan pada Eclipse jauh lebih banyak dan bervariasi dibandingkan IDE lainnya.

\section{Metodologi DAD (Disciplined Agile Delivery)}

Tahap perancangan sistem bertujuan sebagai persiapan untuk merancang sistem,pembuatan sketsa bagaimana sistem dibentuk dan memberikan gambaran yang jelas kepada pengembang untuk membangun sistem. Perancangan sistem ini dengan menggunakan metodologi DAD dimana terdapat 3 fase pengembangan. Metodologi DAD (Disciplined Agile Delivery) DAD (A mbler and Lines, 2012) merupakan sebuah proses kerangka kerja yang menitikberatkan pada beberapa karakteristik seperti: people first, learningoriented hybrid agile approach to IT solution delivery

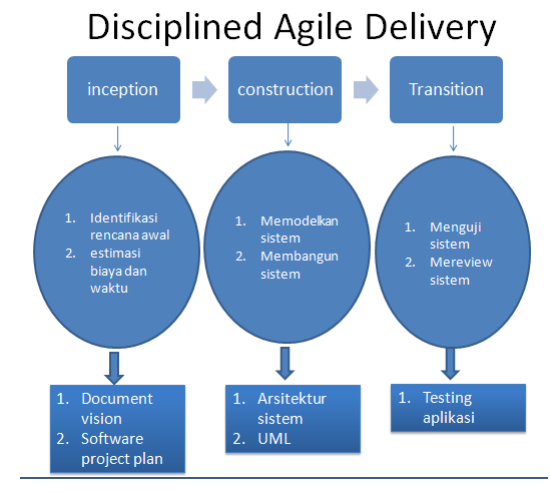

Gambar 2 Fase Pengembangan

Daur hidup DAD memperluas siklus konstruksi Scrum dalam tiga hal penting:

1) Inception. Fase Proyek yang eksplisit, yakni memungkinkan delivery software secara iterative dalam bentuk kecil dan berlanjut hingga banyak. Sehingga stakeholder dapat segera mengetahui setiap perkembangan dalam perangkat lunak.

2) Contstruction. Mencakup keseluruhan praktek pengembangan software. Proses kerangka kerja DAD dimulai dari pendefinisian kebutuhan perangkat lunak dan pemodelan arsitektur aplikasi, dengan menekankan prinsip pengembangan perangkat lunak yang tepat, sesuai permintaan user.

3) Transition. Penguatan praktek disiplin rekayasa perangkat lunak. Siklus hidup pengembangan perangkat lunak yang berdisiplin, dijamin dengan melakukan uji setiap persyaratan user dibangun. Umpan balik sangat ditekankan untuk dilakukan diantara tim pengembang.

\section{METODOLOGI PENELITIAN}

Sesuai dengan Gambar 2 metodologi penelitian ini menggunakan metodologi Disciplined Agile Delivery yang mempunyai 3 fase inception,construction dan transition. Pada tahap ini di bagi 2 tahap yang pertama tahap inception dan contruction sedangkan tahap kedua yaitu tahap transition testing aplikasi

A. Tahap Inception

a) Dokumen Vision

Diawali dengan laporan dari document vision untuk mengidentifikasi rencana awal serta menganalisa dan untuk mengidentifikasi fitur yang di butuhkan guna mencegah terjadinya masalah yang dapat memakan biaya yang besar dalam perancangan.

- Identifikasi rencana awal merupahkan problem statement matrix yang disusun untuk mengidentifikasi masalah 
yang akan di cari solusinya sebagai perencanaan awal.

- Software Project Plan

Software Project Plan berisi tentang inisiasi dan manajemen proyek yang telah di gabung. Pada proses ini di lakukan identifikasi terhadap batasan di lingkungan proyek, estimasi kasar terhadap biaya dan waktu dan mempersiapkan lingkungan pengerjaan proyek

\section{B. Tahap Construction}

\section{a) Arsitektur Sistem}

Rancang bangun aplikasi pemesanan tiket online kapal laut berbasis Android terdiri dari server dan client (user dan admin) user adalah semua masyarakat yang akan membeli tiket sedangan admin adalh petugas yang mengelola data pelanggan yang memesan tiket. Berikut adalah gambar sistem yang akan di rancang.

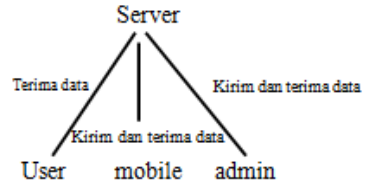

Gambar 3 Sistem perancangan

- Model Fungsional dan Struktural

Permodelan Fungsional ini akan menjelaskan fungsi dari tiap tiap aktor terhadap sistem. Pemodelan ini berisi use case diagram.sedangkan Pemodelan in akan menjelaskan mengenai class diagram berdasarkan use case diagram. Pemodelan ini menjelaskan suatu hubungan antara kelas kelas yang ada pada sistem, sebelum merancang class diagram terlebih dahulu melakukan list berdasrkan objek, yang mengacu pada use case diagram.

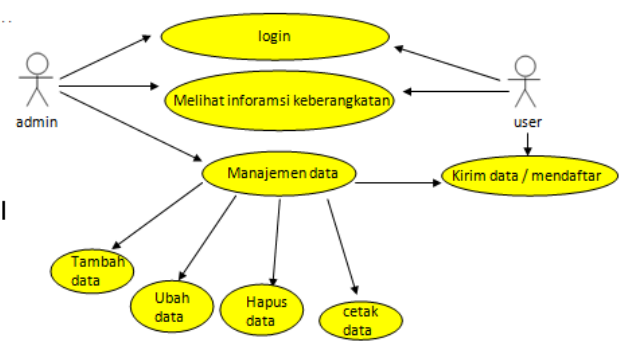

Gambar 4 Use case Diagram

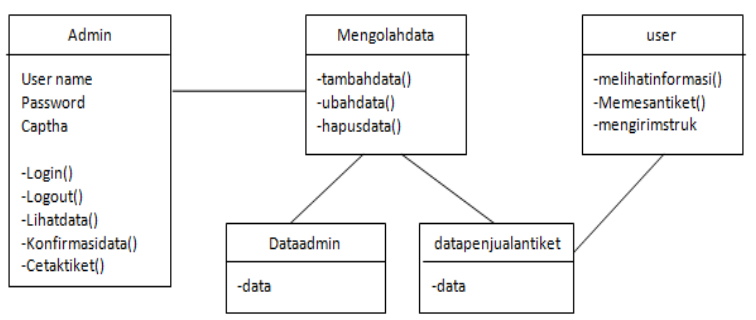

Gambar 5 Class Diagram

- Model Basis Data

Pemodelan jenis ini akan menjelaskan mengenai Entity Relationship Diagram (ERD) dari basis data / database dari sistem yang di pakai ini menggunakan aplikasi MySQL. Terd iri dari entity member. Kapal, deck, booking tiket, dan transaksi. Relasi mengelola mencakup dalam menambah, mengubah dan menghapus data.

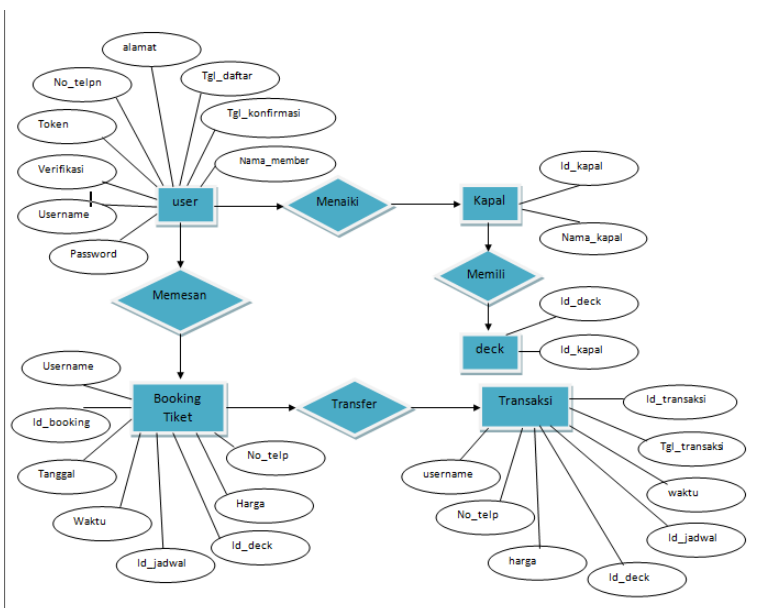

Gambar 6 Entitiy Relationship Diagram

b) Storyboard Perancangan Sistem

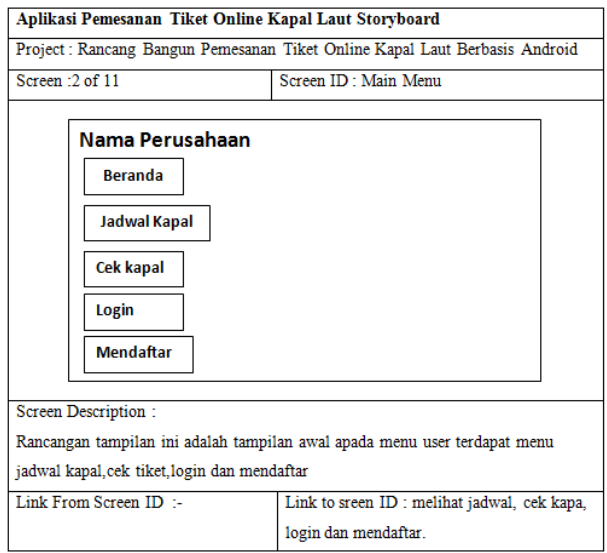

Gambar 7 Stroyboard menu user 
Storyboard pada gambar 7 adalah menu user yang di dalamnya terdapat fitur beranda, jadwal kapal, cek tiket, login dan mendaftar sebagai user. Sedangkan pada gambar 8 storyboard admin fitur di dalamya dalah data master, jadwal, transaksi, daftar booking, cetak tiket, pembatalan tiket, konfirmasi booking, struk pembayaran dan admin.

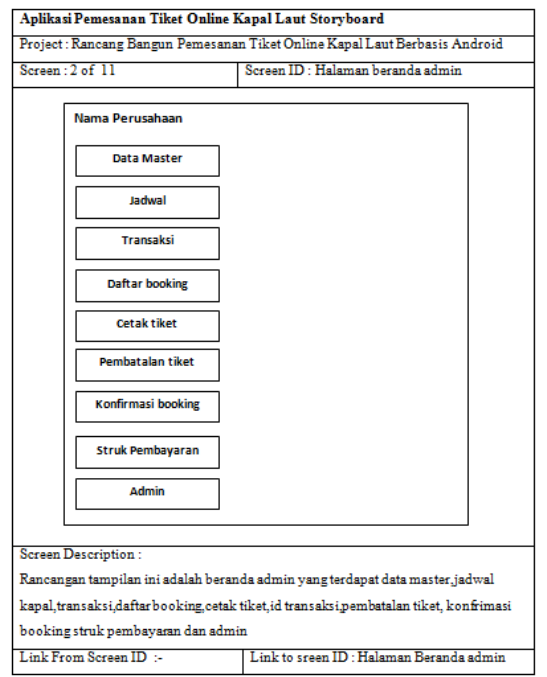

Gambar 8 Stroyboard Admin

\section{HASIL DAN PEMBAHASAN}

\section{A. Membangun Sistem}

Hasil proses pembuatan berdasarkan perancangan aplikasi pemesanan tiket online kapal laut pada menu user terdapat fitur beranda,jadwal kapal, cek kapal,login me mber dan mendaftar men jadi me mber.

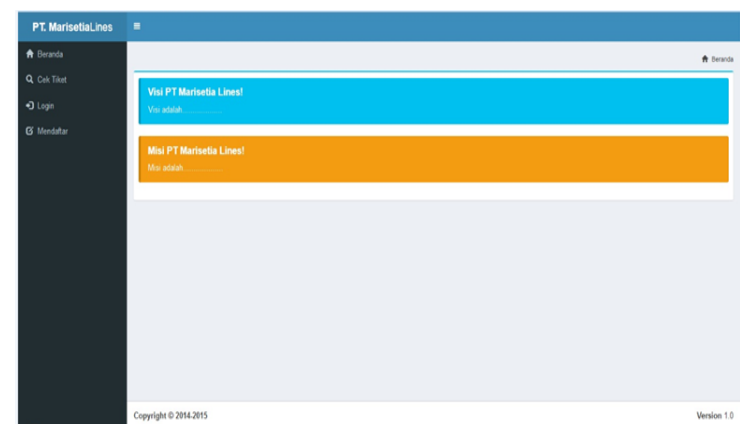

Gambar 9 Halaman awal user

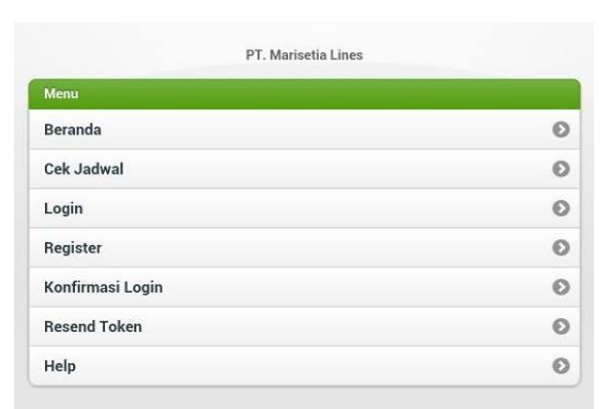

Gambar 10 Halaman user pada android
Sebelum booking tiket user terlebih dahulu mendaftar dan kemudian login user. Pada menu user dapat melihat jadwal kapal dengan tujuan ke masing-masing tujuan kemudian memilih kapal sesuai dengan jadwal keberangkatan

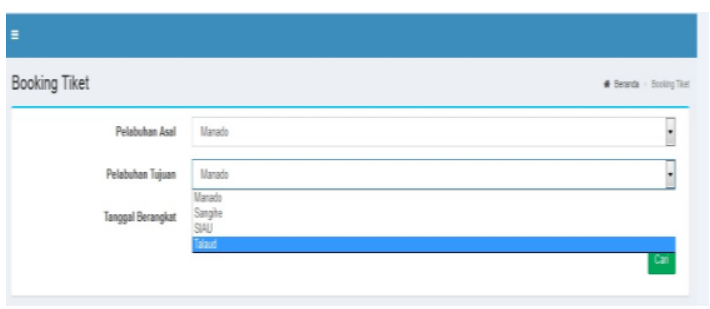

Gambar 11 Halaman booking tiket

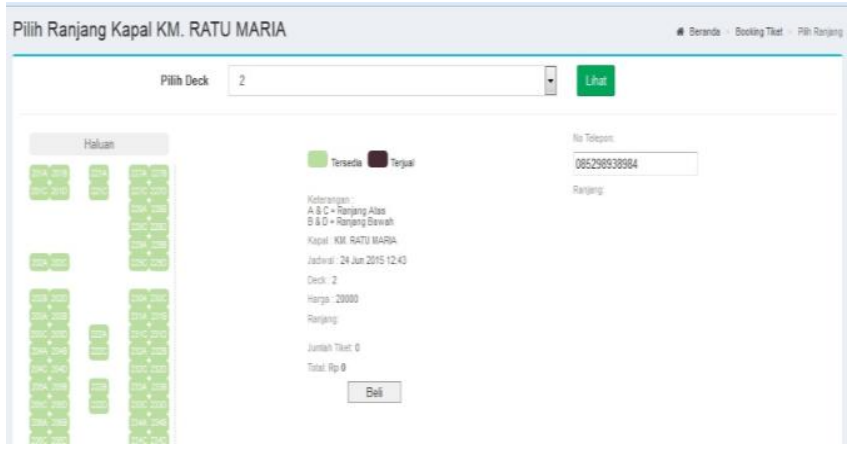

Gambar 12 Me milih deck dan ranjang

Setelah user memilih deck dan ranjang yang akan di gunakan maka sistem akan mengirim nomor rekening perusahaan untuk melakukan proses pembayaran sesuai dengan jumlah yang harus di bayar dengan transfer antar bank. Setelah struk pembayaran telah di konfirmasi maka user melakukan cetak tiket di loket penjualan

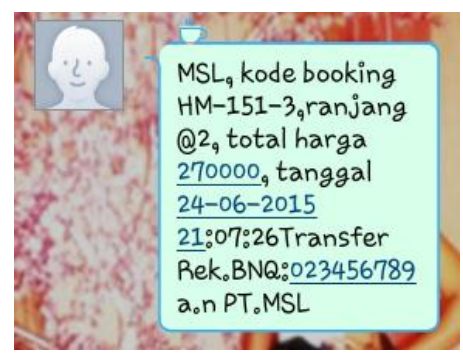

Gambar 13 Pemberitahuan pembayaran

Pada gambar 13 sistem akan mengirim pe mberitahuan pembayaran memalui sms dan user harus membayar sesuai dengan harga yang harus di bayar. 


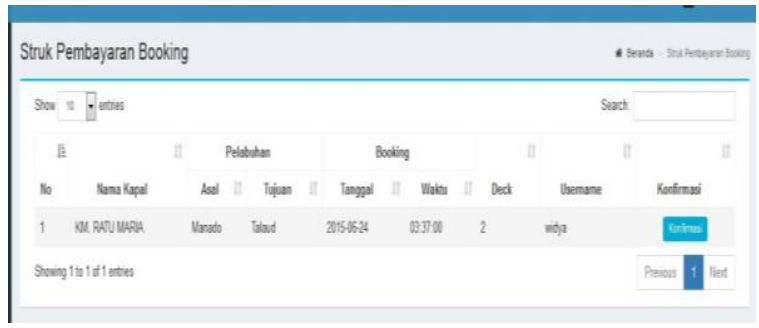

Gambar 14 Konfirmasi Struk Pembayaran

Setelah me mbayar maka user mengirim gambar struk ke menu upload tiket dan admin akan konfirmasi tiket

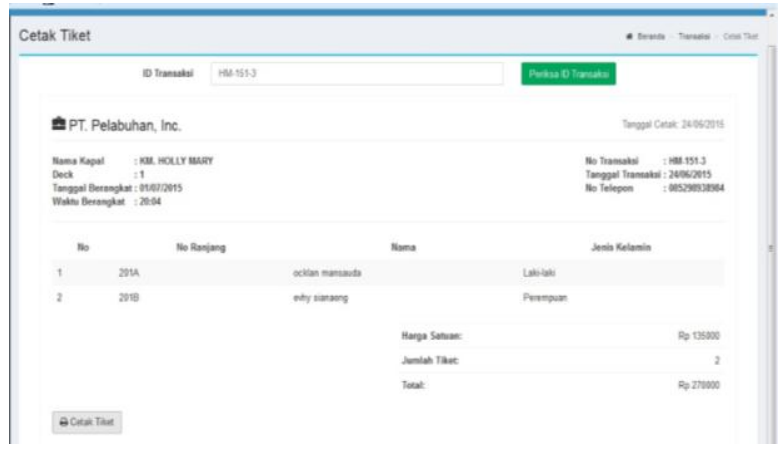

Gambar 15 Id Transaksi Cetak Tiket

pada gambar 15 user memasukan id transaksi setelah kirim struk pembayaran kemudian admin akan mencetak tiket.

\begin{tabular}{|c|c|c|c|c|c|}
\hline \multicolumn{6}{|c|}{ PI PELAYARAN AGRA MARISETIA LINES } \\
\hline 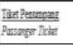 & KM. HOLLY MARY & & & & 1.151-3. \\
\hline 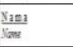 & enty sianang & & & 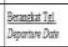 & 01-07-2015 \\
\hline beskent & 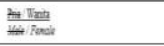 & 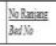 & $201 B$ & 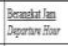 & 20.04 \\
\hline Par-Aipan & 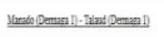 & & & Praniat & 135000 \\
\hline
\end{tabular}

\section{Gambar 16 Tiket Kapal}

Pada gambar 16 adalah hasil dari cetak tiket

\section{B. Tahap Transition}

Pada tahap ini adalah tahap setelah sistem telah dibangun, pada tahap ini dilakukan ujicoba untuk mengetahui spesifikasi minimum pada aplikasi yang menjalankan sistem, baik itu ujicoba dengan menggunakan personal computer dan mobile sebagai user. Pada spesifikasi personal computer yang di gunakan adalah processor intel core i3, memori RAM 2GB,sistem operasi windows 7 dan browser mozilla firefox. Pada spesifikasi mobile yang di gunakan adalah sistem operasi android (Samsung Tab 3 Lite) dan browser internet.

\section{Testing Aplikasi}

Tahap ini berisi tentang testing aplikasi pada 5ystem yang telah di buat dengan menggunakan selenium IDE 2.9.0 plugin Mozilaa Firefox. Cara kerja selenium IDE yaitu merekam pengujian berdasarkan form-form data yang di masukan

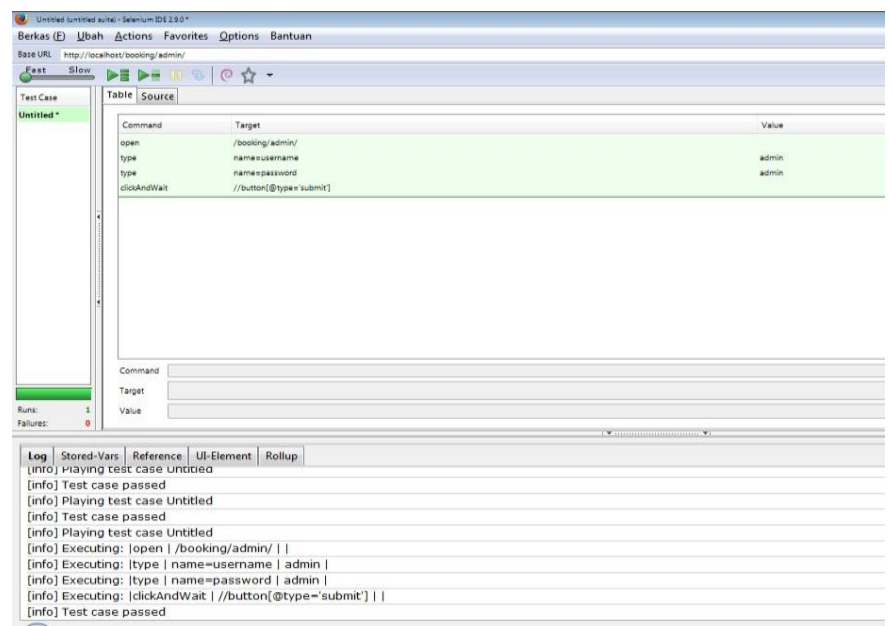

Gambar 17 Testing Aplikasi

\section{KESIMPULAN}

Kesimpulan yang didapat: Sistem yang telah di rancang telah berhasil dibangun untuk di implementasikan sebagai kebutuhan syarat sarjana Teknik Informatika Unsrat.

Untuk menunjang perancangan aplikasi maka di gunakan metodologi perancangan DAD (Disciplined Agile Delivey).

Pada perancangan Web dan Android di gunakan Bahasa Pemograman PHP dan Java. Sedangkan untuk android di gunakan Eclipse sebagai tools pengembang perangkat lunak..

Website dan Aplikasi Mobile pemesanan tiket dapat di gunakan sebagai sarana penyampaian informasi tentang Kapal, pelabuhan, jadwal keberangkatan dan lain sebagainya.

\section{SARAN}

Saran pengembangan sistem kedepannya adalah menambahkan fitur lokasi penjualan tiket dan kapal pada peta serta dapat menampilkan rute jalan menuju lokasi.

\section{DAFTAR PUSTAKA}

[1] Ambler, Lines, 2012. Disciplined Agile Delivery: A Practitioner's Guide to Agile Software Delivery in the Enterprise. IBM Press

[2] Pressman Roger, 2001, Rekayasa Perangkat Lunak. Buku 1, Penerbit Andi, Yogyakarta.

[3] Suarga, 2009. Dasar Pemrograman Komputer Dalam Bahasa Java. Andi Offset, Yogyakarta. 
[4] Safaat, Nazruddin. 2012, Pemograman Aplikasi Mobile Smartphone dan Tablet PC Berbasis Android, Bandung: Penerbit Informatika.

[5] Muhamad. Ichwan. 2013, Aplication Programming Interface pada Aplikasi Mobile Android. Bandung : Instutut Teknologi Nasional.

[6] Sutarman [2003] ;Membangun Aplikasi Web dengan PHP \& MySQL, Graha Ilmu, Yogyakarta.

[7] Kadir, Abdul[2002]; Dasar Pe mograman web Dinamis menggunakan PHP,Penerb it Andi Yogyakarta, edisi Kedua.

[8] Herma wan S, Stephanie 2011, Mudah Membuat Aplikasi Android, Andi, Yogyakarta.

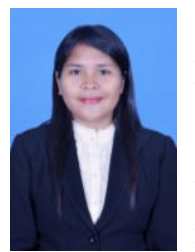

Sekilas dari penulis dengan nama lengkap Deybi Widya Eirene Sede, lahir pada tanggal 11 Desember 1992 di Kabupaten Kepulauan Sangihe tepatnya di kota Tahuna Sulawesi Utara. Anak ke 3 dari 3 bersaudara dengan memu lai pendidikan sekolah dasar d SD

Inpres Eneratu Tahuna. Kemudian pada tahun 2004 melanjutkan ke Sekolah Menengah Pertama SMP Negri 1 Tahuna dan pada tahun 2007 melanjutkan ke SMK Negri 1 Tahuna. Setelah lulus pada tahun 2010 penulis melanjutkan ke Perguruan Tinggi tepatnya di Universitas Sam Ratulangi Manado dengan mengambil jurusan Teknik Informatika. Pada tahun 2014 bulan November penulis membuat skipsi demi memenuhi syarat sarjana (S1) dengan penelitian yang berjudul Rancang Bangun Aplikasi Pemesanan Tiket Online Kapal Laut Berbasis Android yang di bimbing oleh kedua dosen Teknik Informatika Alicia A. E. Sinsuw,.ST.,MT dan Xaverius B.

N. Najoan.,ST.,MT sehingga pada tanggal 23 Oktober 2015 penulis resmi lulus di Teknik Informatika Universitas Sam Ratulangi dan menyandang sebagai Sarjana Ko mputer dengan predikat sangat memuaskan. 